\title{
GEOSTRATEŠKI POMEN VODNIH VIROV SLOVENIJE
}

\author{
Dušan Plut *
}

Izvleček:

UDK: 911.3:556(497.4)

Avtor obravnava temeljne geografske značilnosti in geostrateški pomen vodnih virov Slovenije. $V$ primerjavi $z$ večino drugih evropskih držav so vodni viri Slovenije obilni. Vendar je hkrati značilna zelo neenakomerna prostorska razporeditev in sezonska nihanja vodnega stanja. Gospodarski in geostrateški pomen vodnih virov zmanjšuje praviloma slaba kakovost tekočih voda. Za vodno oskrbo s pitno vodo slovenske reke niso primerne, kakovost talne vode in vodnoekološko zelo občutljivih kraških izvirov pa ogrožajo praviloma neprečiščene odpadne vode in druge oblike obremenjevanja okolja. Čiščenje odpadnih vod in smotrna raba vodnih virov je tudi strateško pomembna, sonaravno zasnovana naloga.

Ključne besede: Vodni viri, kraški izviri, onesnaževanje voda, oskrba s pitno vodo, poplave, Slovenija.

\section{Abstract:}

The paper discusses basic geographical features and geostrategic interest of water resources in Slovenia. In comparison with other European countries Slovenia has abundant water resources which, however, are unevenly distributed and characteristic of seasonal watertable oscillations. In many cases, the economic and geostrategic interest of water resources is diminished by the poor water quality of streams. Slovenian rivers are not suitable for water supply, while the quality of groundwaters and karst springs which are very sensitive in view of water-ecology are jeopardized in many cases by the untreated waste waters and other forms of environmental pollution. Waste waters' treatment and reasonable exploitation of water resources are also strategically important and sustainably devised tasks.

Key words: Water resources, Karst springs, Water pollution, Drinking water supply, Floods, Slovenia.

\footnotetext{
* Izr: prof. dr., Oddelek za geografijo Filozofske fakultete, Aškerčeva 2, Ljubljana
} 


\section{UVOD}

$\mathrm{Z}$ rastjo svetovnega prebivalstva, porabe vode na prebivalca in naraščanjem odpadnih voda se vse več območij sveta sooča s pomanjkanjem količinsko in kakovostno ustrezne sladke vode. $\mathrm{V}$ zadnjih štirih desetletjih se je svetovno prebivalstvo podvojilo, količine načrpane vode pa več kot početverile:

* $1000 \mathrm{~km}^{3}$ - leta 1950

* $3000 \mathrm{~km}^{3}$ - leta 1975

* $4400 \mathrm{~km}^{3}$ - leta 1990

* nad $5200 \mathrm{~km}^{3}$ - leta 2000 (ocena)

Zato bo kakovostna sladka voda ob hrani in energiji temeljna strateška dobrina človeštva 21. stoletja. Pomanjkanje sladke vode in naraščajoče onesnaževanje vodnih virov je že omejitveni dejavnik gospodarskega in družbenega razvoja $v$ številnih državah, ne le v sušnih območjih sveta (Shiklomanov, 1993, str. 13). V 20. stoletju, zlasti v njegovi drugi polovici, se je zaradi hitrega naraščanja porabe vode in s tem povezanega povečanja onesnaževanja vodnih virov, pojavila potreba po njihovem trajnem varovanju.

T.i. mednarodna porečja (na ozemlju večjega števila držav) obsegajo 47 \% kopnega (brez upoštevanja Antarktike) in okoli 60 \% ozemlja Afrike in Latinske Amerike. Nekateri strokovnjaki opozarjajo na naraščanje političnih nasprotij zaradi uporabe mednarodnih rek (Nil, Jordan, Tigris, Evfrat, Ganges itd.), jezer in izvirov, ki lahko prerastejo v vojaške spopade (McCaffrey, 1993, str. 92). V zadnjih letih pa so $\mathrm{z}$ vso silovitostjo izbruhnili mednarodni spori zaradi onesnaževanja $v$ zgornjih delih porečja, ko onesnaževanje $\mathrm{v}$ povirju ogroža gospodarsko rabo in vodno oskrbo nižje ležeče države (npr. onesnaženost Rena s težkimi kovinami, onesnaženost $s$ cianidi in težkimi kovinami v porečju Tise itd.).

21. stoletje bo zaradi pričakovanega nadaljnjega povečevanja svetovnega prebivalstva in porabe na prebivalca označevala povečana uporaba vodnih virov, torej povečani količinski in onesnaževalni pritiski na vodne vire. Hkrati pa bo v bodoče še večja zaskrbljenost zaradi onesnaževanja voda ter negotovost o možnih hidrografskih učinkih globalnega segrevanja. V območjih vodnega pomanjkanja in prekomerne rabe pa ni izključena možnost oboroženih spopadov, vojn za omejene vodne vire (Jones, 1997, str. 20). Zaradi pičlih in onesnaženih vodnih virov naraščajo napetosti med naselji, regijami in državami. Voda postaja strateški in geopolitični dejavnik, ki bo zanesljivo pomembno zaznamoval 21. stoletje. $\mathrm{V}$ začetku devetdesetih let 20. stoletja je bilo na svetu okoli 600 milijonov prebivalcev v državah s pičlimi obnovljivimi letnimi vodnimi viri (pod $2000 \mathrm{~m}^{3}$ na prebivalca). Do leta 2025 naj bi po nekaterih ocenah 3 milijarde ljudi živelo v državah, kjer bo občasno ali trajno primanjkovalo vode (Postel, 1996, str. 67). Države z bogatimi in kakovostnimi vodnimi viri pa lahko z veliko večjo varnostjo pričakujejo razvojne in okoljske izzive prihodnosti.

\section{GEOGRAFSKE ZNAČILNOSTI TEKOČIH VODA SLOVENIJE}

Vodni tokovi Slovenije prejemajo vodo z ozemlja, ki obsega nad $43000 \mathrm{~km}^{2}$, površina državnega ozemlja pa je $20256 \mathrm{~km}^{2}$ (Lah, 1996). Drava in Mura, ki pritečeta v Slovenijo, imata zgornji del porečja v Avstriji, Drava v povirju tudi v Italiji.

V Sloveniji je povprečno $1567 \mathrm{~mm}$ padavin oziroma $1005 \mathrm{~m}^{3} / \mathrm{s}$. Od padavinske vode se v ozračje z izhlapevanjem vrača $417 \mathrm{~m}^{3} / \mathrm{s}$ ali $41,5 \%$, po rekah pa odteče $588 \mathrm{~m}^{3} / \mathrm{s}$ ali $58,5 \%$ $\left(18,8 \mathrm{~km}^{3}\right)$ (Kolbezen, 1998a, str. 139). Letna količina padavin je dvakrat nad svetovnim 
povprečjem kopnega $(800 \mathrm{~mm})$, bistveno večji pa je tudi odtočni količnik (kopno - $35 \%$, Slovenija $59 \%)$. Odtok vode iz ozemlja Slovenije $(917 \mathrm{~mm})$ je v primerjavi z evropskim povprečjem $(319 \mathrm{~mm})$ skoraj trikrat večji. Slovenija je torej zelo vodnata (Radinja, 1979), saj jo označuje velik odtok iz lastnega ozemlja ter hkrati večje količine vode iz sosednje Avstrije (13,2 $\mathrm{k} \mathrm{m}^{3}$ oziroma $41 \%$ pretoka po ozemlju Slovenije). Skupaj se preko ozemlja Slovenije pretoči na leto približno $32 \mathrm{k} \mathrm{m}^{3}$ vode oziroma 32 milijard $\mathrm{m}^{3} /$ leto (Kolbezen, 1998a, b). V Sloveniji znašajo letne interne rečne vode $9250 \mathrm{~m}^{3}$ na prebivalca letno, $v$ Evropi pa $4700 \mathrm{~m}^{3}$. Ob upoštevanju vseh vod, ki se pretakajo po ozemlju Slovenije (zlasti dotok rečne vode iz Avstrije), pa je na prebivalca letno na razpolago $16000 \mathrm{~m}^{3}$ skupne rečne vode.

Slovenija je razvodna in povirna, kjer se tekoče vode šele oblikujejo, kljub veliki namočenosti je vodna mreža drobna in šibka (Radinja, 1979). Ozemlje Slovenije označuje gosta rečna mreža, ki znaša $v$ povprečju $1,33 \mathrm{~km} / \mathrm{km}^{2}$ (Kolbezen, 1998a). Razvoj rečne mreže na ozemlju Slovenije je posledica geološkega razvoja, zakrasevanja, poledenitve in pretočitev. Zaradi velike reliefne razgibanosti Slovenije in njene kamninske zgradbe (prepletanje kraškega in nekraškega reliefa) so tekoče vode kratke. Od skupne dolžine 26989 km tekočih voda jih je $10000 \mathrm{~km}$ ali $37 \%$ hudourniških. Le 46 slovenskih rek je daljših od $25 \mathrm{~km}$, njihova dolžina pa pomeni petino skupne dolžine tekočih voda (Kolbezen, 1998a, b). Večina rečnega omrežja je vezana na štiri glavne reke: Savo, Sočo, Dravo in Muro. Med mejnimi rekami sta največji Kolpa in Sotla.

Zlasti zaradi padavinskih režimov so za manjše reke značilna zelo izrazita sezonska nihanja vodostajev in pretokov. Večje reke naraščajo in upadajo počasneje, zlasti če imajo v zaledju več kraškega sveta, prodnih ravnin in kotlin ter gozdov. Pri večini vodni tokov maksimalni pretoki za več kot stokrat presegajo minimalne, razen Drave in Mure ter nekaterih kraških rek oziroma izvirov (Krka, Prečna).

Z izjemo Mure in Drave so za vse druge reke značilni zelo izraziti pretočni nižki v poletju, običajno julija in zlasti avgusta, pa tudi septembra. V Pomurju in Podravju lahko tedaj tudi nekateri daljši vodni tokovi zaradi močnega izhlapevanja skoraj presahnejo (Ledava, Pesnica, Ščavnica). Zelo nizki poletni pretoki, višje temperature, skromen strmec manjših subpanonskih, summediteranskih in delno tudi kraških rek alpskega in dinarskega sveta zelo povečajo poletno občutljivost večine vodni tokov in težave vodne oskrbe.

Poplave v Sloveniji so zelo različne in odsev pokrajinske pestrosti. Pojavljajo se naslednji tipi poplav (Orožen Adamič, 1992, str. 7; Brilly et al., 1999, str. 10): »nižinske« poplave, hudourniške poplave, poplave na kraških poljih in poplave morja.

Poplave ogrožajo na Slovenskem nad $3000 \mathrm{~km}^{2}$ ozemlja, najpogostejše pa so v ozkih dolinskih dneh vzdolž hudourniških grap ter na okrog 30 obsežnih poplavnih območij v razširjenih delih dolin (Ljubljansko Barje, porečje Dravinje, Krke, Spodnja Savinjska dolina itd.) na kraških poljih (Planinsko polje, Cerkniško polje) in ob morju. Največkrat jih povzročajo siloviti nalivi, pa tudi hitro taljenje snega. Zaradi zelo različnih vremenskih in podnebnih vplivov nastopajo poplave na naših rekah v vseh letnih časih, z viškom jeseni in spomladi (Šifrer, 1983). Zelo velika poplava je bila junija 1954 na območju Celja, v večjem delu Slovenije pa tudi novembra 1990 in novembra 1998. Tako so velike količine padavin v začetki novembra 1990 povzročile katastrofalno poplavo zlasti v Zgornji Savinjski dolini. Ob poplavi se je sprožilo veliko zemeljskih plazov. Pri 
Podvolovjeku je zemeljski plaz zajezil odtok vode, prišlo je do prelivanja vode in porušitve pregrade (Brilly et al., 1999, str. 10).

Človek je na obseg in pogostost poplav v Sloveniji delno sovplival s krčenjem gozdov, kmetijsko obdelavo, gradnjo naselij in infrastrukrure, obrati na vodni pogon (mlini, Žage), gradnjo HE, regulacijami vodni tokov itd. Z najrazličnejšimi posegi je spremenil fiziognomijo in gospodarsko rabo na poplavnih območij (Šifrer, 1983; Natek, 1992). V zadnjih petdesetih letih je propadlo nekaj tisoč mlinov in žag, ki so z jezovi stoletja blažili hiter odtok naraslih voda. Za varstvo pred poplavami potekajo že več kot sto let obsežna regulacijska dela. Poplavne vode se prenašajo v spodnje dele porečja, kjer se hkrati povečuje površina naselij v poplavnih območjih. V obdobju 1973 - 1988 je bilo melioriranih 63637 ha vlažnih in zamočvirjenih površin, zgrajeni so bili nekateri večnamenski zadrževalniki, vendar poplav niso v celoti preprečili (Kolbezen, 1989b, str. 153). Postavljati se je začelo tudi vprašanje o ekološki ustreznosti in ekonomski upravičenosti melioracijskih in regulacijskih ukrepov.

V Sloveniji pa se po ugotovitvah K. Natka (1983) zaradi neenakomerne razporeditve padavin preko leta, velikih nihanj v letnih množinah ter različnih ostalih klimatskih, litoloških, geomorfoloških in drugih dejavnikov dokaj pogosto pojavljajo tudi sušna obdobja. Sušnost je praviloma v Sloveniji klimatsko pogojena, povzroča tudi nizek vodni pretok, kar ogroža oskrbo z vodo, proizvodnjo električne energije v HE, občutno pa poveča občutljivost vodnih virov na onesnaževanje. Nizki vodostaji na naših rekah znižujejo gladino in količino podtalnice $\mathrm{v}$ naplavinah, od koder dobiva pitno in industrijsko vodo večina slovenskih mest (Ljubljana, Maribor, Celje, Kranj, Murska Sobota, Ptuj itd.).

\section{VODNOOSKRBNA IN ENERGETSKA VLOGA VODNIH VIROV SLOVENIJE}

Med viri oskrbe s pitno vodo so najpomembnejša območja talne vode (54\% vse načrpane vode) in kraški izviri (43\%), le nekaj odstotkov pa se črpa iz površinskih vod (reke). Pomembnejši izviri omogočajo izkoriščanje okoli $26 \mathrm{~m}^{3} / \mathrm{s}$ pitne vode, podtalnice pa so za polovico skromnejše $\left(12,4 \mathrm{~m}^{3} / \mathrm{s}\right.$ ) (Lah, 1998, str. 38).

Skupne dinamične zaloge podzemeljske vode (talne in kraške) v Sloveniji znašajo 50,4 $\mathrm{m}^{3} / \mathrm{s}$. Dinamične zaloge talne vode (prodno peščene, dobro prepustne rečne naplavine) so $18,8 \mathrm{~m}^{3} / \mathrm{s}$ ali $37 \%$ vseh podzemeljskih dinamičnih zalog Slovenije. Vodonosniki $z$ medzrnsko poroznostjo skupaj obsegajo $3726 \mathrm{~km}^{2}$ oziroma 18,4 \% površja Slovenije (Bat, 1997; Panjan, 1998). Območja podtalnice so kotline in rečne doline, ki so zasute s terciarnimi in kvartarnimi prodnimi ter peščenimi nanosi. V rečnoledeniških nanosih Mure, Drave, Savinje, Save, Soče in nekaterih njihovih pritokih so razmeroma obsežna območja talne vode: Apaško polje, Mursko polje, Dravsko polje, Ptujsko polje, Spodnja Savinjska dolina, Kranjsko polje, Sorško polje, Ljubljansko polje, Brežiško - Krško polje, Soško polje itd.

Talna voda, ki pokriva več kot polovico slovenskih potreb po pitni vodi, je ogrožena predvsem zaradi vse večjih količin odpadne vode in neprimernih dejavnosti nad vodnoekološko občutljivimi območji. Kmetijstvo in druge dejavnosti pomembno vplivajo zlasti na kakovost plitvih podtalnic (globina do vode manj kot $10 \mathrm{~m}$ oziroma $5 \mathrm{~m}$ ). Apaško, Mursko, Prekmursko, Ptujsko polje in Spodnja Savinjska dolina so bila v prvi polovici devetdesetih let med najbolj ogroženimi (Mikulič, 1992; Brečko, 1998). Poslabšala se 
je zlasti kakovost talne vode Dravskega polja, Ljubljanjskega polja, dela Sorškega polja in ob Savinji.

Kraški svet obsega v Sloveniji okoli $44 \%$ ozemlja, prisotni so tudi vodnoekološko različno občutljivi tipi krasa, od visokogorskega do nizkega krasa (Gams, 1974; Kunaver, 1984). Kraški izviri so temeljni vir vodne oskrbe s pitno vodo zlasti v alpski in dinarskokraški Sloveniji. Specifičnost gibanja kraške podzemeljske vode podčrtujejo tudi podzemeljske razvodnice porečja, ki se pogosto ne ujemajo s površinsko (topografsko) razvodnico. Njihovo ugotavljanje zato temelji predvsem na sistematičnemu sledenju podzemeljskih voda. S pomočjo barvanja ponikalnic so v Sloveniji ugotovili velika odstopanja med površinsko in podzemeljsko kraško razvodnico ter številna podzemeljska križanja in razcepljanja voda. Na našem krasu je bilo po 2. svetovni vojni opravljenih več kot sto sledenj z največjo oddaljenostjo $41 \mathrm{~km}$ in večmesečnim potovanjem sledila (Kranjc, 1998, str. 92). Nekateri kraški izviri se ob različnih vodnih stanjih oskrbujejo z vodo iz različnih porečij. Kraška voda lahko torej ob različnih vodostajih teče $v$ različne smeri, kar otežkoča določanje varstvenih pasov in varstvenih režimov za oskrbo s pitno vodo zajetih kraških izvirih.

Onesnaževanje kraških voda je posledica skromnih samočistilnih sposobnosti porečij in vodnih virov ter razmeroma velikih količin pretežno neprečiščenih odpadnih voda. V Sloveniji je okoli $9000 \mathrm{~km}^{2}$ (44 \% celotnega ozemlja) kraškega površja, s kraškimi vodnimi viri skromnih samočistilnih zmogljivosti (Habič, 1992). Viri onesnaževanja kraških izvirov so zelo različni, od gospodinjstev, industrije, obrti, kmetijstva, prometa itd. Na krasu še ne poznamo dovolj zaledja vodnih virov, zaradi razlik v površinski in podzemeljski razvodnici pa zelo težko natančno določimo možne vire onesnaževanja. Potrebne so nadaljnje raziskave in sledilni poskusi. Le poznavanje smeri in hitrosti raztekanja z določenega kraškega območja, zaledja zajetih kraških izvirov omogoča uspešno varovanje izvirov in pravilno predvidevanje v primeru nesreče. Posledice onesnaževanja z nevarnimi kemikalijami kraških izvirov so dolgotrajne in večplastne, kar kaže primer več desetletij onesnažene belokranjske Krupe s polikloriranimi bifenili (Plut, 1988).

Tudi izvedeni sledilni poskus leta 1997 Inšituta za raziskovanje krasa ZRC SAZU (Postojna) na območju vojaškega poligona Poček (Javorniki) je pokazal večplastnost problematike občutljivosti in varovanja kraških izvirov. Ugotovljena je bila široka, razvejana mreža podzemeljskih povezav: z Malenščico (Malni pri Planini), podzemno Pivko v Planinski jami in zelo oddaljeno Vipavo $(24,6$ km), izviri v Rakovem Škocjanu, pa tudi v Strženu pri Stari vasi in občasnem izviru Škratovke na Planinskem polju. Rezultati sledenja (hitrosti pretakanja in deleži sledila uranina) s pojavljanjem tudi $v$ zajetih izvirih za oskrbo prebivalstva s pitno vodo (Malenščica, Vipava) ponovno opozarjajo na nujnost okoljske previdnosti pri načrtovanju dejavnosti kraških pokrajin. Pozitivno je dejstvo, da je sledenje naročilo Ministrstvo za obrambo RS in sicer v okviru izdelave poročila o presoji vplivov na okolje (v skladu z Zakonom o varstvu okolja) predvsem na zajeti izvir Malenščico v Planini.

Druge analize so pokazale, da vsebnost kadmija, niklja, broma in jodida v prsti Počka presegajo zakonsko dovoljene vrednosti. Hkrati so analize sedimentov izvira Malni (zajet za vodno oskrbo prebivalstva postojnske in pivške občine) v obdobju 1991 - 1993 pokazale občasno naraščanje vsebnosti niklja, kadmija, bakra in cinka. Potencialna vira 
onesnaževanja zajetega izvira sta tudi komunalno odlagališče odpadkov postojnske občine in avtocesta (Kogovšek, 1999; Kogovšek et al., 1999). Upravičena bi bila okoljevarstvena (vodnoekološko zasnovana) členitev vojaškega poligona Poček in temu prilagojene aktivnosti.

Za oskrbo javnih vodovodov je potrebno črpati okoli $8,5 \mathrm{~m}^{3} / \mathrm{s}$ vode $\left(4,5 \mathrm{~m}^{3} / \mathrm{s}-\right.$ povprečni pretok porabljene vode). Povprečna izdatnost zajetih vodnih virov v Sloveniji je 12,1 $\mathrm{m}^{3} / \mathrm{s}$, v daljših sušnih obdobjih pa se zmanjša izdatnost vodnih virov na približno 6,1 $\mathrm{m}^{3} / \mathrm{s}$, kar je manj od normalnih potreb oskrbe s pitno vodo. Po oceni znaša v Sloveniji celotna količina načrpane, odvzete vode (naselja, energetika, kmetijstvo, industrija) okoli $600 \mathrm{~m}^{3}$ na prebivalca oziroma 16441 na prebivalca dnevno (Lah, 1998, str. 38). Poraba vode (brez izgub) na prebivalca $v$ gospodinjstvih je 110 - 1301 dnevno.

Slovensko vodovodno omrežje je močno razdrobljeno, kakovost vodovodnega omrežja pa zaostaja za njegovo razsežnostjo, pomanjkanje čiste vode pa je že v osemdesetih letih postalo v nadpovrečno humidni Sloveniji zelo pereče razvojno vprašanje (Radinja, 1985). Razlike med načrpano in prodano vodo predstavljajo izgube $v$ vodovodnem omrežju, ki znašajo okoli $41 \%$ (okoli 111 milijonov $\mathrm{m}^{3}$ letno). Velike izgube so ena od rezerv za oskrbo prebivalstva, saj jih lahko zmanjšamo na približno $25 \%$ (Okolje v Sloveniji ...1996, 1998; Panjan, 1998). Povprečna poraba vode iz javnih vodovodov je bila 240 l/preb/dan. V Sloveniji je bilo leta 1995 na javne vodovode ter na manjše vodovode v krajevnih ali vaških skupnosti priključeno $98 \%$ prebivalcev Slovenije.

Najbolj varno vodooskrbo je možno zagotoviti z javnimi vodovodi, vzdrževanjem in zaščitnimi (vodovarstvenimi) pasovi virov pitne vode (Macarol Hiti, 1997). V prvi polovici 90 . let $16 \%$ prebivalcev ni imelo zagotovljenega nadzora kakovosti vode za pitje, leta 1998 pa $12 \%$. Odstotek mikrobiološko oporečnih vzorcev je bil sredi 90 . let okoli $11,5 \%$, leta 1998 pa 10,3\%. Fizikalno kemijsko je bilo neustreznih sredi 90 . let $9,5 \%$ vzorcev, leta 1998 pa 7,2 \% (Macarol Hiti, 1997; Vodooskrba v Sloveniji, 1999). Največji odstotek neustreznih bioloških rezultatov pitne vode je bil leta $1998 \mathrm{v}$ naslednjih območjih nadzora: Ljubljana (35\%), Novo mesto $(20 \%)$ in Ravne na Koroškem (20 $\%)$, sredi 90 . let pa v Celju (40\%), Novem mestu $(28,5 \%)$, Ljubljani $(24,5 \%)$ in na Ravnah $(22 \%)$.

Onesnaženost podtalnice z nitrati je bila zlasti prisotna v nekaterih vzorcih vode črpališč talne vode severovzhodne Slovenije. V nekaterih krajevnih vodovodih Murskega polja je dovoljene normative za nitrate presegala tudi do trikrat (Macarol Hiti, 1997, str. 90). Pesticidi se v pitnih vodah še ne spremljajo sistematično, v posameznih vzorcih (Murska Sobota, Gornja Radgona, IMP Trata, Vodovod Domžale, Slovenske Konjice) pa je vsebnost atrazina presegala dovoljene vrednosti. Opazen je trend naraščanja vsebnosti organskih kloriranih topil.

Po podatkih ankete za leto 1998 je imela le dobra polovica zajetij javnih vodovodov opredeljene vodovarstvene pasove, v več kot tretjini primerov (35\%) pa se varstveni režim ni spoštoval. Odgovori v zvezi z vodovarstvenimi režimi po mnenju Inšituta za raziskovanje zdravja nedvomno kažejo, da je preventiva vodne oskrbe Slovenije šibka (Vodooskrba v Sloveniji, 1999, str. 45).

Po mnenju Rismala (1994) je značilno, da je kakovost vodnih virov v neposredni bližini večjih porabnikov zaradi naraščajočega onesnaževanja in premalo učinkovite zaščite 
ogrožena. Obstajata dve možnosti: črpanje iz bolj oddaljenih vodnih virov (podtalnica, izviri) ali iz bližnjih površinskih vodah po predhodnem čiščenju (Rismal, 1994, str. 388). Onesnaževanje vodnih virov Slovenije je pereč pokrajinsko degradacijski proces in pokrajinska rezultanta zelo različnih samočistilnih sposobnosti slovenskih pokrajin in vodnih virov ter količin in sestave odpadnih voda. V prvi fazi onesnaževanja so bile $\mathrm{z}$ odpadnimi vodami vodnoekološko degradirane površinske, kasneje pa tudi podzemne vode. Velika sezonska spremenljivost pretokov in poudarjeni nižki bistveno vplivajo na skromne samočistilne sposobnosti slovenskih rek v poletnih sušnih obdobjih. V primerjavi s koncem osemdesetih let se je do srede devetdesetih let izboljšala kakovost površinskih vod in delno poslabšala kakovost vode nekaterih podtalnic ter kraških izvirov. Konec 90. let je bila le slaba polovica (48 \%) prebivalcev Slovenije priključena na kanalizacijsko omrežje (brez upoštevanja priključenosti na greznice) in le petina na čistilne naprave (primarno in sekundarno čiščenje).

Pogosta uporaba tekoče vode za pogon mlinov, žag, obrtnih delavnic, fužin in glažut je označevala energetsko vlogo naših rek v preteklosti. V zadnjih desetletjih pa je najpomebnejša vloga tekočih voda pri proizvodnji električne energije, ki je vse ostale oblike rabe potisnila $v$ ozadje in podrejen položaj. Slovenija je v letu 1996 proizvedla 11,5 milijard kWh električne energije, od tega so hidroelektrarne prispevale okoli $30 \%$. HE so po 2. svetovni vojni proizvedle 103 milijarde $\mathrm{kWh}$ električne energije in tako prihranile 103 milijone ton premoga (Kolbezen, 1998b, str. 157).

Skupna instalirana moč slovenskih HE na večjih rekah je okoli $700 \mathrm{MW}$, njihova povprečna proizvodnja pa je okoli 3200 GWh (Janežič, Somrak, 1995). Najpomembnejši je sistem osmih HE na Dravi (okoli $500 \mathrm{MW}$ ), ki je edina v celoti energetsko izkoriščena reka tudi zaradi energetsko ugodnih najvišjih pretokov v poletnih mesecih. Ob visokih pretokih delujejo dravske HE kot pretočne, ob nižjih pa kot HE s pretočno akumulacijo. Na Soči so tri večje HE ter več manjših s skupno instalirano močjo nad 80 MW. Voda za HE Doblar se zbira v akumulacijskem jezeru pri Mostu na Soči, ostali dve soški HE pa sta pretočni (Natek K., Natek M., 1998). Na Savi so zgrajene $4 \mathrm{HE}$ (Moste, Mavčice, Medvode in Vrhovo), načrtuje pa se gradnja verige HE med Zidanim mostom in Mokricami. Jezovi velikih HE so v času vojaških spopadov ali terorizma pogosto cilj napada.

Na večjih slovenskih rekah bi bilo tehnično možno zgraditi še HE s skupno močjo okoli $1400 \mathrm{MW}$ in srednjo letno proizvodnjo nad $4200 \mathrm{GWh}$, energetsko najugodnejši potencial za majhne HE pa se ocenjuje na okoli 100 MW (Janežič, Somrak, 1995), tehnično izkoristljiv srednjih in malih vodni tokov (brez Mure, Drave, Save in Soče) pa okoli 500 MW. Vendar bi bistveno povečevanje obstoječih HE (npr. HE Moste na Savi pri Jesenicah), zlasti pa širokopotezna gradnja HE, zahtevala veliko prostora za akumulacije vode, obstajajo pa še številni tehtni naravovarstveni in drugi zadržki (npr. proti gradnji HE na Muri, Radovni, zgornji Soči, Planinskem polju itd.).

$\mathrm{V}$ preteklosti je bila tudi vodnoekološko pomembna vloga okoli 4000 bodnih obratov. Jezovi so delno zadržali vode ob povodnjih in povečevali samočistilno zmogljivost (prezračevanje vode). Počasi se povečuje število majhnih HE (njihova skupna moč je okoli $35 \mathrm{MW}$ ), vendar graditelji vedno ne spoštujejo naravovarstvenih omejitev. Zlasti vprašljiva je njihova gradnja $\mathrm{v}$ občutljivem alpskem svetu. 


\section{SMERNICE STRATÉŠKO IN SONARAVNO ZASNOVANEGA UPRAVLJANJA VODNIH VIROV SLOVENIJE}

Celovito, hidrogeografsko kompleksno in geostrateško zasnovano upravljanje s količinsko bogatimi vodnimi viri Slovenije vključuje ukrepe pokrajinskega varstva površinske in podzemeljske vode zaradi naslednjih temeljnih nalog:

1. zagotavljanje stalne razpoložljivosti kakovostne vode za sedanjo vodno oskrbo prebivalstva in dejavnosti;

2. zagotavljanje kakovostne vode za naravne ekosisteme;

3. zagotavljanje kakovostne vode za kritje potreb prihodnjih generacij.

Sonaravna (trajnostna) strategija vodnih virov (smotrna, pretehtana raba vode $\mathrm{v}$ okviru hitrosti obnavljanja in samočistilnih sposobnosti) Slovenije bo morala vsebovati širok niz ukrepov, ki bodo:

* zaščitili površinsko in podzemeljsko vodo

* zagotovili stalno razpoložljivost vode za uporabo

* zagotavljali potrebno količino vode za naravne ekosisteme

* podpirali trajnostno sonaravni gospodarski razvoj z zapiranjem krogov rabe vode

* minimizirali možnost ogrožanja prebivalcev zaradi namerne zastrupitve virov pitne vode ali poškodbe visokih jezov

Prednostne strateške usmeritve upravljanja z vodnimi viri v Nacionalnem programu varstva okolja (NPVO) (1998) so naslednje:

* vodni viri - eden od ključnih dejavnikov sonaravnega razvoja

* zmanjšanje obremenjevanja točkastih virov (industrija, živinorejske farme, komunalne odpadne vode)

* zmanjšanje obremenjevanja iz razpršenih virov (intenzivno kmetijstvo, razpršena poselitev, promet)

* sanacija starih bremen, ki ogrožajo vodno okolje

* višja stopnja čiščenja odpadnih voda $\mathrm{v}$ pokrajinsko in gospodarsko specifičnih območjih (kras, alpski svet, Pomurje, turistična območja)

* sanacija in preprečitev neustreznih posegov $\mathrm{v}$ vodno okolje

Do leta 2008 je predvidena gradnja naslednjih novih čistilnih naprav ( $\breve{C N}$ ) v večjih mestih (Nacionalni program ..., 1998, str. 39):

* Ljubljana - $500000 \mathrm{PE}$

* Maribor - $200000 \mathrm{PE}$

* Celje - $80000 \mathrm{PE}$

* Nova Gorica - $45000 \mathrm{PE}$

* Izola - $30000 \mathrm{PE}$

* Trbovlje - 30000 PE

* Tržič - $15000 \mathrm{PE}$

Ocena stroškov izvajanja programov ukrepov NPVO znaša letno okoli 1,5\% BDP. Za varstvo voda se za obdobje 1990 - 2003 predvideva največji delež in sicer $51 \%$ vseh predvidenih stroškov izvajanja NPVO. Glavni nosilec bremena stroškov naj bi bil javni sektor, ki naj bi po predvidevanjih kril 77 \% vseh stroškov, privatni sektor pa $23 \%$. Zaradi nakopičenih okoljskih bremen, zdravstvenih in ekonomskih posledic onesnaževanja okolja je bistveno povečanje sredstev brez dvoma potrebno. Prav tako je upravičeno prednostno 
reševanje nakopičenih vodnoekoloških problemov zaradi notranjih vzrokov (težave z vodno oskrbo, zmanjšan turistični potencial države zaradi onesnaženih vodnih virov, ogroženost pokrajinske in biotske raznovrstnosti itd.) in zunanjih vzrokov (približevanje okoljskim stadardom in trajnostno sonaravnemu modelu EZ).

Slovenija je torej bogata $z$ vodnimi viri, vendar se že srečuje s pomanjkanjem kakovostne in dostopne pitne vode (Plut, 1998). Neobhodna je smotrna raba vode, zmanjšanje porabe in izgub, celovito čiščenje odpadnih voda, zaščita virov pitne vode (zlasti kraških izvirov in območij talne vode), sanacija divjih in legalnih odlagališč odpadkov na območjih virov pitne vode, zmanjšanje obremenitev kmetijstva in drugih porabnikov prostora v porečjih in zaledju podzemnih virov pitne vode, renaturacija obvodnega sveta ter nekaterih rek.

Obilje voda je ena največjih strateških primerjalnih prednosti Slovenije, zlasti razsipna poraba, onesnaževanje in posegi v geomorfologijo rečnih bregov pa to prednost izničujejo. Temeljno vodilo bi zato morala biti vodni bilanci in različnim samočistilnim sposobnostim vodnega okolja prilagojena in smotrna raba vode (vodno oskrba, energetska, turistično rekreacijska in druga).

\section{LITERATURA}

- Bat M., 1997: Vodovje, Enciklopedija Slovenije zvezek 11, Ljubljana, Mladinska knjiga.

- Brečko V., 1998: Pokrajinska občutljivost območij podtalnic z vidika kmetijstva, Zbornik posveta Kmetijstvo in okolje, Ljubljana, str. 49 - 56.

- Brilly M., Mikoš M., Šraj M., 1999: Vodne ujme, FAGG, Ljubljana.

- Gams I., 1974: Kras, Slovenska matica, Ljubljana.

- Janežič S., Somrak D., 1995: Energetska izraba vodnih sil Slovenije, Zavod za tehnično izobraževanje, Ljubljana, str. 9/1 - 14.

- Jones J, 1997: Hydrology - Processes, Resources and Environmental Management, Longman, Harlow.

- Kogovšek J., 1999: Nova spoznanja o podzemnem pretakanju vode v severnem delu Javornikov (visoki kras), Acta Carsologica 28/1, Ljubljana, str. 161 - 200.

- Kogovšek J., Knez M., Mihevc A., Slabe T., Šebela S., 1999: Military Training Area in Kras (Slovenia), Environmental Geology 38, Springer Verlag, str. 69 - 67.

- Kolbezen M., 1998a: Hidrogeografija, Geografija Slovenije, Slovenska matica, Ljubljana, str. 139 - 172

- Kolbezen M., 1998b: Kopenske vode, Geografski atlas Slovenije, DZS, Ljubljana, str. 94 - 95.

- Kranjc A., 1998: Kraške vode, Geografski atlas Slovenije, DZS, str. 92 - 93.

- Kunaver J., 1984: The High Mountain in the Slovene Alps, Geographica Iugoslavica V, Ljubljana, str. 15 - 24.

- Lah A., 1996: Pogled v prostor in čas, Geographica Slovenica 28, Ljubljana.

- Lah A., 1998: Voda - vodovje, Zbirka Usklajeno in sonaravno 1998/2, Svet za varstvo okolja RS, Ljubljana.

- McCaffrey V., 1994: Water, Politics and Environmental Law, Water in Crisis, Oxford University Press, New York - Oxford, str. 92 - 104.

- Mikulič Z., 1992: Hidrološki vidiki varovanja kakovosti podtalnic na Slovenskem, Ujma 6, Ljubljana, str. 133 - 140.

- $\quad$ Natek K., 1983: Ogroženost Slovenije zaradi suše, Naravne nesreče v Sloveniji, Ljubljana, str. 94 - 99.

- Natek K., Natek M., 1998: Slovenija, Mladinska knjiga, Ljubljana.

- Natek M., 1992: Nekateri vidiki poplavnega sveta v geografski luči, Poplave v Sloveniji (zbornik), Republiška uprava za zaščito in reševanje, Geografski inšitut Antona Melika ZRC SAZU, Ljubljana, str. $21-30$.

- Nacionalni program varstva okolja, 1998, Ministrstvo za okolje in prostor, Ljubljana, str. 102.

- Okolje v Sloveniji 1996, 1998: Ministrstvo za okolje in prostor, Uprava RS za varstvo narave, Ljubljana. 
- Orožen Adamič M., 1992: Pregled poplav v Sloveniji, Poplave v Sloveniji (zbornik), Republiška uprava za zaščito in reševanje, Geografski inšitut Antona Melika ZRC SAZU, Ljubljana, str. 7 - 10.

- Panjan J., 1998: Temelji geografskega informacijskega sistema za vodovode in kanale v Sloveniji, Ujma 12, Ljubljana, str. 133 - 135.

- Plut D., 1988: Belokranjske vode, Dolenjski muzej, Novo mesto.

- Plut D., 1998: Pokrajinski vidiki vloge vodnih virov v sonaravnem razvoju Slovenije, Okolje 1998/1 - 2, Ljubljana str. 23 - 31.

- Postel S., 1996: Sporazum z vodo, Zemlja 1996 (prevod), Medium Radovljica, str. 45 - 67.

- Radinja D., 1979: Pokrajinske značilnosti industrializacijske onesnaženosti $\vee$ Sloveniji, Geographica Slovenica 9, Ljubljana, str. 75 - 84.

- Radinja D., 1985: Sodobna oskrba s pitno vodo v SR Sloveniji in njeno vodovodno omrežje, Geografski vestnik LVII, Ljubljana, str. 19 - 34.

- Rismal M., 1994: O preskrbi s pitno vodo, Okolje v Sloveniji (zbornik), Tehniška založba, Ljubljana, str. 387 - 391.

- Shiklomanov I., 1993: World Fresh Water Resources, Water in Crisis, Oxford University Press, Oxford, str. $13-24$.

- Šifrer M., 1983: Vzroki in učinki rečnih poplav v Sloveniji, Naravne nesreče.v Sloveniji, Ljubljana, str. 41 - 49.

- Vodooskrba v Sloveniji (leta 1998), 1999: Inštitut za varovanje zdravja RS, Ljubljana.

\section{GEOSTRATEGIC INTEREST OF WATER RESOURCES IN SLOVENIA}

Dušan PLUT, Associate professor, Department of Geography, Faculty of Arts, Aškerčeva 2, 1000 Ljubljana, Slovenia

\section{SUMMARY}

By the side of food and oil, water also transforms into an ever more important strategic and geopolitical factor which will, most probably, determine the $21^{\text {st }}$ century. Countries with abundant and good-quality water resources will further retain their developmental and strategic advantages. An important task in developmental and environmental policy is to pursue environmentally friendly water management adjusted to the available water resources. Slovenia receives rather abundant precipitation and abounds in water resources. About 32 $\mathrm{km}^{3}$, or 32 billion $\mathrm{m}^{3}$ of water runs annually on Slovenian territory where 18.5 billion $\mathrm{m}^{3}$ also originate, which is $9,250 \mathrm{~m}^{3}$ of internal waters per inhabitant per year, while the Europan average amounts but $4,700 \mathrm{~m}^{3}$. When all the streams on the territory of Slovenia are taken into account, the yearly amount is $16,000 \mathrm{~m}^{3}$ of the river water per inhabitant. However, the water resources in Slovenia are spatially very unevenly distributed. The littoral, karstic and subpannonian regions of Slovenia suffer water deficit in summertime, of drinking water in particular. Because the streams mainly begin as headwaters the river network is dense, yet the streams of minor discharges only prevail. Karstic features of the surface (44\% of the state territory), explicit seasonal oscillations of river discharges (summer minimum), and modest vertical drops in the rivers' bottom sections reduce the self-purifying capacities of rivers and springs.

However, characteristic are also extremely high discharges, so that diverse types of floods recurring on about $3,000 \mathrm{sq} \mathrm{km}$ are also typical of Slovenia. Since the areas exposed to floods have been built up the flood-caused damages increase. 
Exploitation of hydro-power (hydro-power plants contribute one third of electric energy), drainage of waste waters and water supply are the basic modes of exploitation of water resources in Slovenia. Owing to polluted rivers, the karstic springs and groundwaters are the most important sources for the supply of drinking water to people and their activities. These resources, too, are slightly polluted which results from the modest self-purifying capacities and the pollution. The water quality of karst springs and groundwaters slightly impaired during the last ten years, while the quality of surface waters improved in the same period. In the mid-nineties, only a mean half (48\%) of the population of Slovenia was connected to public utility (connections to cesspools are not included), and only one fifth was connected to treatment facilities (primary and secondary treatment). Even waste waters from the biggest towns (Ljubljana, Maribor and Celje) are mainly discharged untreated into the rivers. To provide sufficient quantities of qualitative drinking water has already become a very demanding task in numerous regions.

The sustainable strategy of managing water resources in Slovenia should proceed from their availability and self-purifying capacities, which would provide strategically reliable water supply, economic development and functioning of sensitive aquatic and peri-aquatic ecosystems. 